\title{
ANALISA AKUNTABILITAS DAN TRANSPARANSI TENTANG IMPLEMENTASI KEBIJAKAN PENGELOLAAN BOS
}

\author{
Nurul Hariswati \\ Pascasarjana Fakultas Ekonomi dan Bisnis Universitas Brawijaya Malang \\ E-mail: nurulhariswati@yahoo.co.id
}

\begin{abstract}
This research was conducted with the aim to analyse the implementation of the accountability and transparency financial management which the source stemming from government. The approach used is a case study of indepth interview from financial manager, head master, and stakeholders. The results of this research show that first appeared as constraints and not regulated and obligations of private schools in terms of taxation. Second, the scale of priority importance of accountability between the financial manager and head master has different values so as conflicts of interest. Third, the implementation of transparency development from the publication such as via the website, call center, facebook. The fourth, the Government has $n$ ot set a standard policy to use of the grant allocations.
\end{abstract}

Keywords: Financial management, Accountability, Transparency, Conflicts of Interest.

\begin{abstract}
Abstrak
Penelitian ini dilakukan dengan tujuan untuk menganalisis implementasi akuntabilitas dan transparansi pengelolaan keuangan yang sumbernya berasal dari bantuan pemerintah serta menemukan hambatan dan kendala teknik. Pendekatan yang digunakan adalah studi kasus dengan tehnik indepth interview dengan informan pelaksana teknik keuangan, pengambil keputusan, dan stakeholder. Hasil penelitian ini menunjukan bahwa pertama, menimbulkan kendala dan hambatan seperti, tidak diatur hak dan kewajiban sekolah swasta dalam hal perpajakan. Kedua, skala prioritas tingkat kepentingan akuntabilitas antara bendahara dan kepala madrasah mempunyai nilai yang berbeda sehingga menimbulkan konflik kepentingan Ketiga, implementasi transparansi yang sifatnya modern seperti publikasi via website, call center, facebook. Keempat, kebijakan pemerintah belum mengatur standar pagu terhadap alokasi penggunaan dana bantuan yang berkaitan langsung dengan kepentingan siswa dan sifatnya operasional yang dapat mendukung secara tidak langsung terhadap kepentingan siswa.
\end{abstract}

Kata kunci: Pengeloalan keuangan, Akuntabilitas, Transparansi, Konflik Kepentingan.

Pemerintah mengeluarkan program Bantuan Operasional Sekolah yang bertujuan meri- ngankan beban biaya pendidikan yang digunakan untuk membiayai kebutuhan sekolah. 
Sesuai dengan peraturan pemerintah No. 48 tahun 2008 tentang Pendanaan Pendidikan yang menyatakan bahwa Pendanaan pendidikan menjadi tanggung jawab bersama antara pemerintah, pemerintah daerah, dan masyarakat. Perwujudan dari peraturan pemerintah ini munculnya bantuan pemerintah bagi lembaga pendidikan.

Ada beberapa kecenderungan penyelewengan pengelolaan bantuan pemerintah tersebut, seperti munculnya fenomena pemberitaan yang mengupas tentang penyelewengan bantuan pemerintah. Penyelewengan bantuan operasional sekolah seperti BOS dan DAK (Dana Alokasi Khusus) oleh pihak sekolah menjadi sebuah sorotan penting dalam sebuah topik dari sebuah stasiun televisi swasta. Dalam topik ini dikupas bahwa ada beberapa kasus korupsi pengelolaan dana BOS sejumlah 44 kasus sebesar Rp10,5 milyar danDAK sebesar Rp78 milyar. (ICW dikutip dariANTV pada acara "Topik Petang", 2012).

Faktor yang menyebabkan meningkatnya penyelewengan dana $\mathrm{BOS}^{1}$. Pertama adanya peningkatan jumlah dana BOS yang diterima oleh pihak sekolah. Pada tahun 2011, sekolah dasar menerima dana BOS Rp397.000 per murid. Nilai tersebut meningkat menjadi Rp580.000 per murid tahun 2012. Jumlah dana BOS selanjutnya dikalikan dengan jumlah murid yang terdapat disekolah tersebut. Semakin banyak jumlah murid maka semakin besar pula dana BOS yang diterima. Sebaliknya, semakin kecil jumlah murid maka semakin kecil pula dana BOS yang diterima dalam tahun tersebut. Kedua, tidak ada perubahan kualitas tata kelola ( $g o$ vernance) sekolah terutama aspek transpa- ransi, akuntabilitas, dan partisipasi. Hal tersebut terlihat darijuknis (Petunjuk Teknis) dana BOS 2012 yang dikeluarkan Kemendikbud, bahwa pengelolaan dana BOS sama dengan tahun sebelumnya dan tidak ada perubahan signifikan.

Di sisi lain masih ada kelemahan atau "penyakit" dalam penggunaan dana BOS di tingkat sekolah belum juga hilang, yaitu pelanggaran alokasi penggunaan dana BOS untuk gaji guru. Pemerintah menoleransi penggunaan dana BOS untuk gaji guru honorer maksimum hanya $20 \%$ saja, tetapi kenyataanya masih banyak sekolah yang menggunakan dana BOS lebih dari $20 \%$ untuk gaji guru.

Salah satu pertimbangan penelitian ini dilakukan di lingkungan Kemenag kota Blitar karena kondisi satuan pendidikan dasar yang akan dijadikan penelitian ini mempunyai karakteristik sekolah umum yang bercirikan khas Islam. Tingkat heterogenitas sosio kultural satuan pendidikan di kota Blitar sangat memungkinkan untuk dijadikan sebuah penelitian studi kasus. Selain itu, terdapat perbedaan status akreditasi di antara satuan pendidikan akan dapat dijadikan sebagai pertimbangan sebuah penelitian studi kasus. Sehingga dengan pertimbangan ini memungkinkan peneliti untuk mengadakan penelitian ini di wilayah kota Blitar.

Dengan pertimbangan tingkat heterogenitas sosio kultural tersebut peneliti ingin melakukan analisis akuntabilitas dan transparansi serta evaluasi implementasi kebijakan pengelolaan keuangan terhadap beberapa Madrasah Ibtidaiyah swasta di kota Blitar yang bersumber dari bantuan pemerintah yang digunakan untuk operasional sekolah.

\footnotetext{
${ }^{1}$ Agus Rustandi dalam artikel yang berjudul "Dana BOS Triwulan 1/2012 sudah Bocor 10 persen" sebuah blog ICW, Jakarta 15 Februari 2012
} 


\section{Metode Penelitian}

Ditinjau dari tujuannya, studi kasus penelitian ini menggunakan pendekatan deskriptif yang membantu secara tepat pengidentifikasian kaitan timbal balik yang perlu dianalisis, bahkan secara kuantitatif. Pemahaman deskriptif menuntun ke arah perhitungan, penabulasian, dan penguantifikasian berbagai keputusan. Pendekatan ini digunakan untuk mengidentifikasi tipe peristiwa yang dapat dikuantikasikan (Yin, 2012: 138).

Berdasarkan kerangka analisis atas, fokus penelitian inimenempatkan analisis akuntabilitas dan transparansipengelolaan keuangan sekolah yang berasal dari sumber pendanaan BOS. Dalam penelitian ini, penilaian indikator akuntabilitas dan transparansi dimunculkan dari hasil wawancara yang mendalam (in depth interview) terhadap informan kunci sehingga akan bermunculan indikator akuntabiltas dan transparansi dari satuan pendidikan. Selanjutnya, indikator akuntabilitas hasil temuan tersebut akan diukur untuk menilai tingkat kepentingan informan.

Tiga belas indikator pengelolaan keuangan pada petunjuk teknik pelaksanaan BOS Madrasah Ibtidiyah Swasta (seperti yang telah dijelaskan pada bagian sebelumnya) akan digunakan sebagai pembanding dari indikator temuan yang berasal dari informan kunci. Adapun yang menjadi narasumber dalam penelitian ini adalah: Pertama, Informan dari satuan pendidikan Perwanida. Pemilihan informan dilakukan dengan judgment sehingga hanya mereka yang ahli yang berkompeten dalam menganalisis tingkat akuntabilitas dan transparansi pengelolaan sumber dana BOS, yaitu pengelola keuangan, (kepala madrasah dan bendahara), stakeholders internal (yayasan pendidikan), dan stakeholders eksternal (komite sekolah dan manager BOS di lingkungan Kemenag).
Kedua, Dokumen yang dipakai untuk mendukung dan menambah bukti dari sumber lain yang bisa menambah rincian spesifik lain guna mendukung informasi dari sumber lain seperti APBM (anggaran pendapatan belanja madrasah) dan dokumen lain yang mendukung penelitian ini.

Untuk penelitian studikasus ini, peneliti menggunakan tiga teknik pengumpulan data, yaitu observasi, wawancara mendalam (in depth interview), dan dokumentasi. Darihasil wawancara mendalam (in depth interview) peneliti akan menemukan indikator hasil temuan informan dari ketiga satuan pendidikan yang sudah terklasifikasikan. Tahap selanjutnya, informan kunci tersebut diminta untuk mengisi formAHP (Analytical Hierarchy Process) yang digunakan untuk menilai tingkat kepentingan informan. Untuk membantu mengarahkan informan memberikan bobot indikator hasiltemuannya, penelitimembuat list indikator hasil temuan tersebut.

Selanjutnya, informan memberikan penilaian terhadap indikator hasil temuannya dengan mengisi form pembobotan sesuai dengan aturan AHP. Kemudian, hasil penilaian tingkat kepentingan informan dari setiap satuan pendidikan akan dapat dievaluasi untuk diperbandingkan dengan indikator yang ada pada petunjuk teknik pengelolaan BOS tahun 2012. Demikian pula, bukti rekaman arsip dapat digunakan bersama-sama dengan sumber informasi lain sehingga rekaman tersebut bisa menjadi objek perolehan kembali dan dapat digunakan untuk analisis yang lebih luas (Yin, 2012:107).

Dalam penelitian ini tingkat validitas internal mempunyai nilai tinggi karena mengambil data dengan menggunakan data primer yaitu dengan cara in depth interview. $\mathrm{Na}$ mun sebaliknya penelitian ini mempunyai tingkat validitas eksternal yang rendah karena 
tidak mampu digeneralisasikan karena pada dasarnya tujuan penelitian ini bukan untuk digeneralisasi tetapiuntuk menggali lebih dalam sebuah deskripsi permasalahan dari penelitian multi kasus yang akan mendapatkan hasil penelitian menjadi semakin jelas dan terperinci.

Pengukuran validitas penelitian inimenggunakan dua tahap yaitu, menggunakan indikator temuan dengan teknik triangulasi dan menggunakan bantuan software expert choise. Teknik triangulasi dalam menguji keabsahan data dengan pengecekan data dari berbagai sumber dengan berbagai cara dan berbagai waktu. Untuk itu, peneliti dapat me-recheck temuannya dengan jalan membandingkannya dengan berbagai sumber, metode, atau teori (Sugiyono, 2010:461; Moeleong, 2010: 330).

Pengukuran validitas data yang kedua adalah penggunaan sebuah software expert choise dalam metode Analytical Hierarchy Process yang dapat mengukur indikator kepentingan informan di satuan pendidikan dasar yang sudah terklasifikasikan ke dalam situasi sosial yang lebih sempit di lingkungan Kemenag kota Blitar. Penggunaan expert choise dalam penelitian ini dapat memecahkan masalah yaitu mengukur konsistensi jawaban informan dari indikator hasil temuan setiap situasi sosial yang terpilih, sehingga dapat membantu mengukur tingkat kepentingan informan menjadi lebih obyektif.

Teknik analisis data dalam penelitian ini menggunakan dua tahap. Pertama teknik analisis data dengan menggunakan model Huberman dan Miles. Kedua menggunakan teknik analisaAHP(Analytical Hierarchy Process).

\section{Hasil Penelitian dan Pembahasan}

Dalam petunjuk teknikBOS tidak diatur tentang status bendahara sekolah swasta sama atau tidak seperti sekolah negeri. Demi- kian juga, tidak diatur tentang hak dan kewajiban sekolah swasta dalam hal perpajakan terhadap penggunaan keuangan yang berasal dari sumber dana BOS. Dalam Undang-Undang Nomor 1 Tahun 2004 tentang perbendaharaan negara menyatakan bahwa yang disebut dengan bendahara adalah badan atau orang (pegawai) yang mengelola uang negara dan berasal dari kantor atau satuan kerja kementerian atau lembaga atau pemerintah daerah.

Pengertian ini dipertegas dalam ayat 18 bahwa yang dimaksud bendahara pengeluaran adalah orang yang ditunjuk untuk menerima, menyimpan, membayarkan, menatausahakan, dan mempertanggungjawabkan uang untuk keperluan belanja negara atau daerah dalam rangka pelaksanaan APBN atau APBD pada kantor atau satuan kerja kementerian negara atau lembaga atau pemerintah daerah.

Dari pengertian undang-undang di atas menjelaskan bahwa orang atau pegawai yang mengelola uang Bantuan Operasional Sekolah (BOS) yang dikategorikan sebagaibendahara pengeluaran adalah yang berasal dari kementerian atau lembaga atau pemerintah daerah. Dengan demikian sekolah swasta, lembaga pendidikan swasta, pesantren yang diberikan dana BOS oleh Kementerian Pendidikan Nasional tidak wajib memungut pajak-pajak yang harus dipungut bendahara. Sehingga kewajiban pemungutan pajak oleh bendahara yang bukan negeri tidak termasuk yang ditetapkan dalam undang-undang tersebut dengan alasan dasar hukum yang mewajibkan bukan bendahara namun memungut pajak sebagaimana yang dipungut bendahara negeri sampai saat ini belum ada dasar hukumnya.

Dari hasil wawancara beberapa informan di atas dapat disimpulkan bahwa imple- 
mentasi akuntabilitas di satuan pendidikan Perwanida yang dalam hal ini adalah termasuk kategori sekolah besar menunjukan bahwa sudah ada indikator implementasi akuntabilitas seperti di dalam proses penyusunan awal (RAPBM) sampai menghasilkan sebuah kesepakatan (APBM) yang melibatkan peran stakeholder artinya pihak yayasan dan komite diberi kesempatan untuk memberikan usulan terhadap penyusunan progam sekaligus penganggarannya. Pihak pelaksana dan pengelola keuangan beranggapan ketika laporan pertanggungjawaban satuan pendidikan Perwanida dapat diterima oleh stakeholder maka pertanggungjawaban tersebut dapat dikatakan sebuah pertanggungjawaban yang akuntabel.

Berdasarkan anggaran pendapatan belanja yang diperoleh peneliti untuk tahun anggaran 2010 penerimaan dana BOS dari 721 siswa dengan bantuan sebesar Rp.400.000 per tahun sehingga penerimaan dana BOS sebesar Rp. 288.400.000 yang dialokasikan untuk pengeluaran honorarium sebesar Rp.65.295.840 atau sebesar 23\% dari dana BOS digunakan untuk alokasi anggaran honorarium guru dan pegawai serta pelatih ekstrakurikuler.

Untuk tahun anggaran 2011 jumlah penerimaan dana BOS setiap siswa mendapat bantuan sebesar Rp.400.000 dari 727 siswa per tahun sehingga penerimaan dana BOS sebesar Rp. 290.800.000 yang dialokasikan untuk pengeluaran honorarium sebesar Rp.72.675.840 atau sebesar 25\% dari dana BOS digunakan untuk alokasi anggaran honorarium guru dan pegawai.

Untuk tahun anggaran 2012 jumlah penerimaan dana BOS setiap siswa mendapat bantuan penerimaan dana BOS dari 734 siswa sebesar Rp.580.000 per tahun sehingga penerimaan danaBOS sebesar Rp.425.720.000 yang dialokasikan untuk pengeluaran honorarium sebesar Rp. 179.982.552 atau sebesar $42 \%$ dari dana BOS digunakanuntuk alokasi anggaran honorarium guru dan pegawai serta pelatih ekstrakurikuler.

Darifakta diatas dapat disimpulkan bahwa implementasi penggunaan dana bantuan operasional sekolah disatuan pendidikan Perwanida tidak dapat dikatakan mengalami penyimpangan terutama terhadap alokasi penggunaan honorarium guru dan tenaga kependidikan. Dalam petunjuk teknik BOS tahun 2014 hanya mengatur terhadap penggunan honorarium guru dan tenaga kependidikan untuk sekolah negeri tidak boleh melebihi $20 \%$ dari jumlah total bantuan operasional sekolah.

Dalam ruang lingkup manajemen keuangan sekolah transparansi berarti keterbukaan akan kebijakan keuangan, keterbukaan sumber keuangan dan jumlahnya, keterbukaan penggunaanya serta pertanggungjawabannya sehingga akan mempermudah stakeholder untuk mengetahuinya. Dari indikator keterbukaan informasi publik di atas salah satu indikator menunjukan bahwa pengelolaan dan penggunaan dana yang berasal dari anggaran negara atau daerah, sumbangan masyarakat wajib menyediakan informasi yang berkaitan dengan hal tersebut. Satuan pendidikan Perwanida adalah salah satu sekolah yang bukan negeri yang dapat dikategorikan sebagai organisasi nonpemerintah yang mendapatkan bantuan operasional sekolah yang berasal dari anggaran negara dan anggaran daerah sehingga tidak terlepas dari peraturan kertebukaan informasi publik.

Indikator kebijakan akuntabilitas menggunakan dasar utama dari petunjuk teknik pengelolaan keuangan bantuan operasional sekolah, sedangkan indikator kebijakan transparansi digali dari sumber informan kunci. 
Setelah indikator ditemukan kemudian diukur skala prioritasnya berdasarkan persepsi informan kunci. Pengukuran ini bersifat menyilang, artinya informan kunci yaitu, bendahara satuan pendidikan diberikan beberapa indikator yang telah ditemukan sebelumnya untuk diukur skala prioritasnya. Teknik yang sama juga diterapkan untuk kepala madrasah. Teknik yang ketiga antara bendahara dan kepala madrasah bersama-sama mengukur indikator skala prioritas hasil temuan informan kunci tersebut. Teknik ini digunakan peneliti dengan tujuan sebagai bagian dari triangulasi informasi yang diperoleh peneliti.

Beberapa indikator yang muncul terhadap penggunaan keuangan dari dana bantuan operasional sekolah berasal dari beberapa informan yang berperan sebagai pelaksana teknik, pengambilankeputusan, dan strategi manajemen di satuan pendidikan Perwanida.

Hasil temuan in depth interview dari informan kepala madrasah dan bendahara
Perwanida yang berperan sebagai pelaksana teknik dalam hal ini adalah bendahara BOS dan bendahara sekolah ditemukan beberapa informasi terhadap indikator penggunaan keuangan. Hasil beberapa informasi tersebut dapat direduksi secara ringkas hingga menemukan beberapa indikator akuntabilitas terhadap penggunaan dana BOS Untuk hirarki kriteria akuntabiltas penggunaan dana BOS hasil temuan informan kunci seperti yang terdapat pada aliran gambar 1 .

Dari hasil temuan beberapa informan munculah beberapa indikator akuntabilitas yang digunakan sebagai pengukuran kriteria yang berfungsi untuk mengukur tingkat kepentingan informan yang berperan sebagai pelaksana teknik dan informan sebagai pengambil keputusan dari satuan pendidikan yang berkategori satuan pendidikan kecil.

Berdasarkan hasil analisis tingkat kepentingan kepala madrasah terlihat bahwa skala prioritas tertinggi adalah peningkatan sumber daya manusia. Pengadaan buku teks

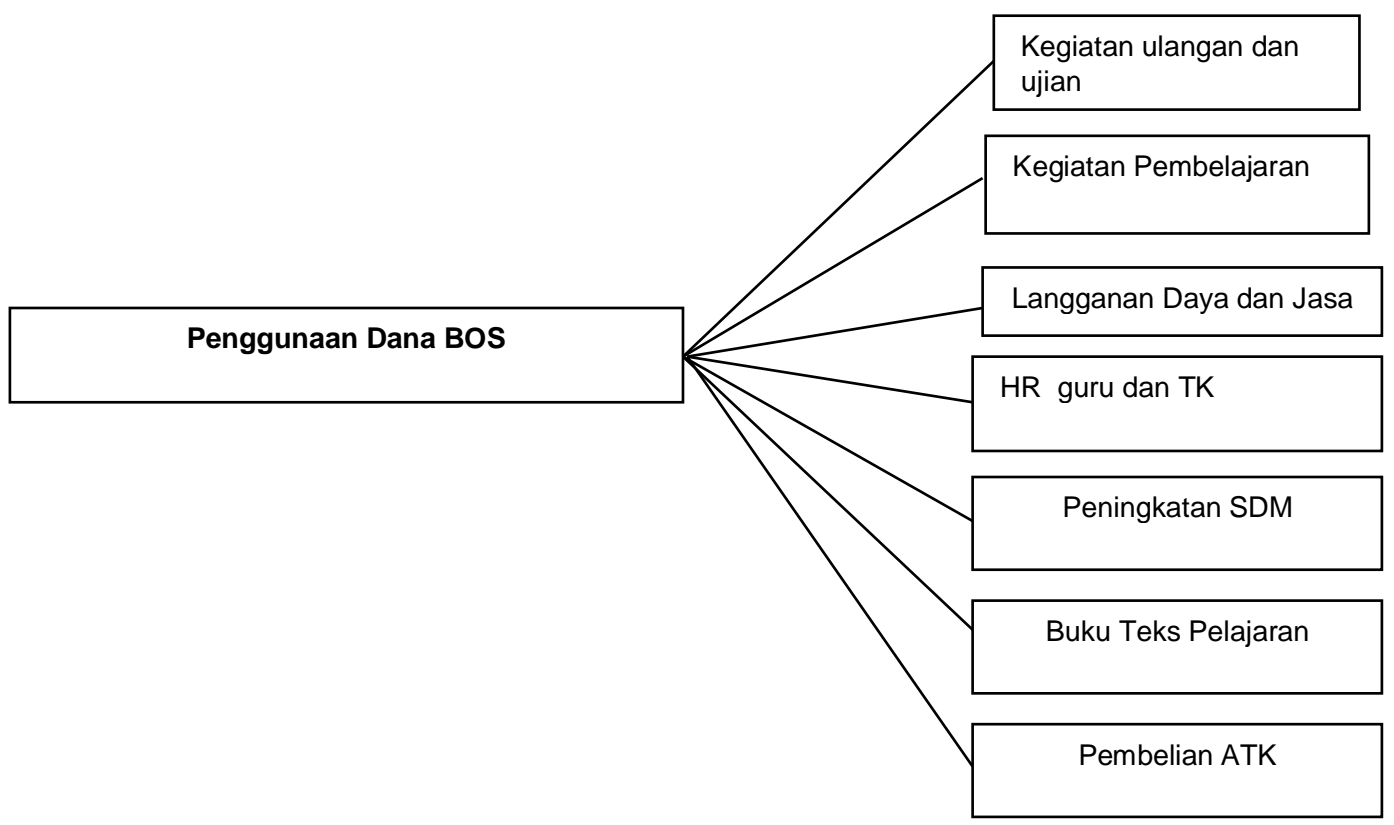

Gambar 1. Penggunaan Dana BOS 
pelajaran menempati skala prioritas kedua setelah peningkatan SDM. Tingkat kepentingan honorarium guru dan tenaga kependidikan menempati skala prioritas setelah kegiatan pembelajaran. Tingkat kepentingan berikutnya adalah pembelian alat tulis kantor. Sedangkan skala prioritas selanjutnya, yang mempunyai tingkat kepentingan yang sama adalah kegiatan ulangan serta pembayaran langganan daya dan jasa seperti pembayaran listrik, telepon untuk operasional, website dan kelas internet.

Untuk tingkat kepentingan informan bendahara terjadi perbedaan antara tingkat kepentingan pengadaan buku teks pelajaran dengan tingkat kepentingan lainya. Urutan tingkat kepentingan berikutnya adalah kegiatan pembelajaran dan kegiatan ulangan dan ujian. Honorarium guru dan tenaga kependidikan menempati tingkat kepentingan berikutnya yang nilai skala prioritasnya tidak jauh berbeda dengan langganan daya dan jasa. Skala prioritas pengadaan buku pelajaran dan peningkatan sumber daya manusia menempati tingkat kepentingan yang terakhir dari beberapa tingkat kepentingan yang ditemukan oleh peneliti.

Muncul perbedaan skala prioritas antara tingkat kepentingan kepala madrasah dan bendahara dari pengukuran indikator yang telah ditemukan peneliti yang diukur secara bersamaan antara kepala madrasah dan bendahara yang ditempatkan dalam ruang dan waktu yang bersamaan. Skala prioritas tertinggi adalah kegiatan pembelajaran dan kegiatan ulangan dan ujian, sedangkan urutan skala prioritas berikutnya adalah pengadaan buku teks pelajaran. Langganan daya dan jasa mempunyai skala prioritas yang hampir sama dengan pengadaan buku teks pelajaran. Skala prioritas honorarium guru dan tenaga kependidikan serta pembelian alat tulis kantor mempunyai nilai kepentingan yang hampir sama. Urutan tingkat kepentingan yang mempunyai skala prioritas terakhir adalah peningkatan sumber daya manusia.

Dapat disimpulkan bahwa penggunaan sumber dana yang berasal dari bantuan operasional di satuan pendidikan Perwanida 54,8\% untuk kepentingan yang berkaitan langsung dengan siswa seperti: kegiatan pembelajaran, kegiatan ulangan dan ujian, pengadaan buku teks pelajaran. Sedangkan selebihnya sebesar 45,2\% dipergunakan untuk mendukung kegiatan pembelajaran seperti: langganan daya dan jasa, honorarium guru dan tenaga kependidikan, pembelian alat tulis kantor dan peningkatan sumber daya manusia.

Dalam petunjuk teknik pengelolaan BOS tidak diatur secara terperinci mengenai prosentase penggunaan dana bantuan ini yang seharusnya dipergunakan untuk kepentingan yang berkaitan langsung dengan kegiatan pembelajaran bagi siswa. Dalam petunjuk teknik BOS tahun 2014 hanya mengatur untuk penggunan honorarium guru dan tenaga kependidikan untuk sekolah negeri tidak boleh melebihi $20 \%$ dari jumlah total bantuan operasional sekolah. Jika ditinjau ulang perarturan ini hanya mengikat terhadap sekolah negeri saja, artinya sekolah swasta tidak terikat terhadap peraturan ini. Selain itu, peraturan tersebut hanya mengatur batas maksimal terhadap tingkat kepentingan honorarium guru dan tenaga kependidikan saja sedangkan tingkat kepentingan yang lain seperti kepentingan yang mendukung secara langsung terhadap kegiatan proses belajar siswa belum diatur secara jelas.

Untuk hirarkikriteria transparansi penggunaan dana BOS dari hasil temuan beberapa informan kunci seperti yang terdapat pada aliran gambar 2 .

Berdasarkan hasil analisis menunjukan bahwa tingkat kepentingan kepala madrasah terhadap transparansi pengelolaan keuangan 
yang menempati skala prioritas tertinggi adalah publikasi informasi laporan keuangan ke walimurid dengan sosialisasi sebelum masuk tahun ajaran baru. Publikasi informasi laporan keuangan pada walimurid secara tertulis dalam bentuk lembaran melalui penerimaan rapor mempunyai skala prioritas kedua. $\mathrm{Pu}-$ blikasi informasi laporan keuangan ke walimurid melalui papan pengumuman dan publikasi informasi laporan keuangan ke walimurid yang ditempatkan pada web site mempunyai nilai kepentingan yang hampir sama, sedangkan skala prioritas yang terakhir adalah publikasi melalui kotak saran, call center, facebook, twitter yang oleh informan dianggap kurang efektif dalam distribusi informasi sekolah baik dari pihak internal sekolah dan stakeholder.

Hasil pengukuran tingkat kepentingan informan bendahara madrasah yang menghasilkan skala prioritas berbanding terbalik dengan kepentingan informan kepala madrasah. Skala prioritas tertinggi adalah publikasi seluruh informasi melalui kotak saran, call center, facebook, twitter, sehingga dapat mempermudah akses informasi. Sama seperti hasil pengukuran tingkat kepentingan informan kepala madrasah bahwa publikasi informasi laporan keuangan pada walimurid secara tertulis dalam bentuk lembaran melalui penerimaan rapor mempunyai skala prioritas kedua. Publikasi melalui papan pengumumanmempunyai skala prioritasketigayang hampir sama dengan skala prioritas publikasi informasi laporan keuangan dalam bentuk tertulis yang ditempatkan pada web site. Sedangkan skala prioritas terakhir adalah publikasi informasi laporan keuangan melalui sosialisasi sebelum masuk tahun ajaran baru.

Hasil yang berbeda terlihat ketika keterbukaan dalam pengelolaan keuangan akan berbeda tingkat kepentingan antara kepala

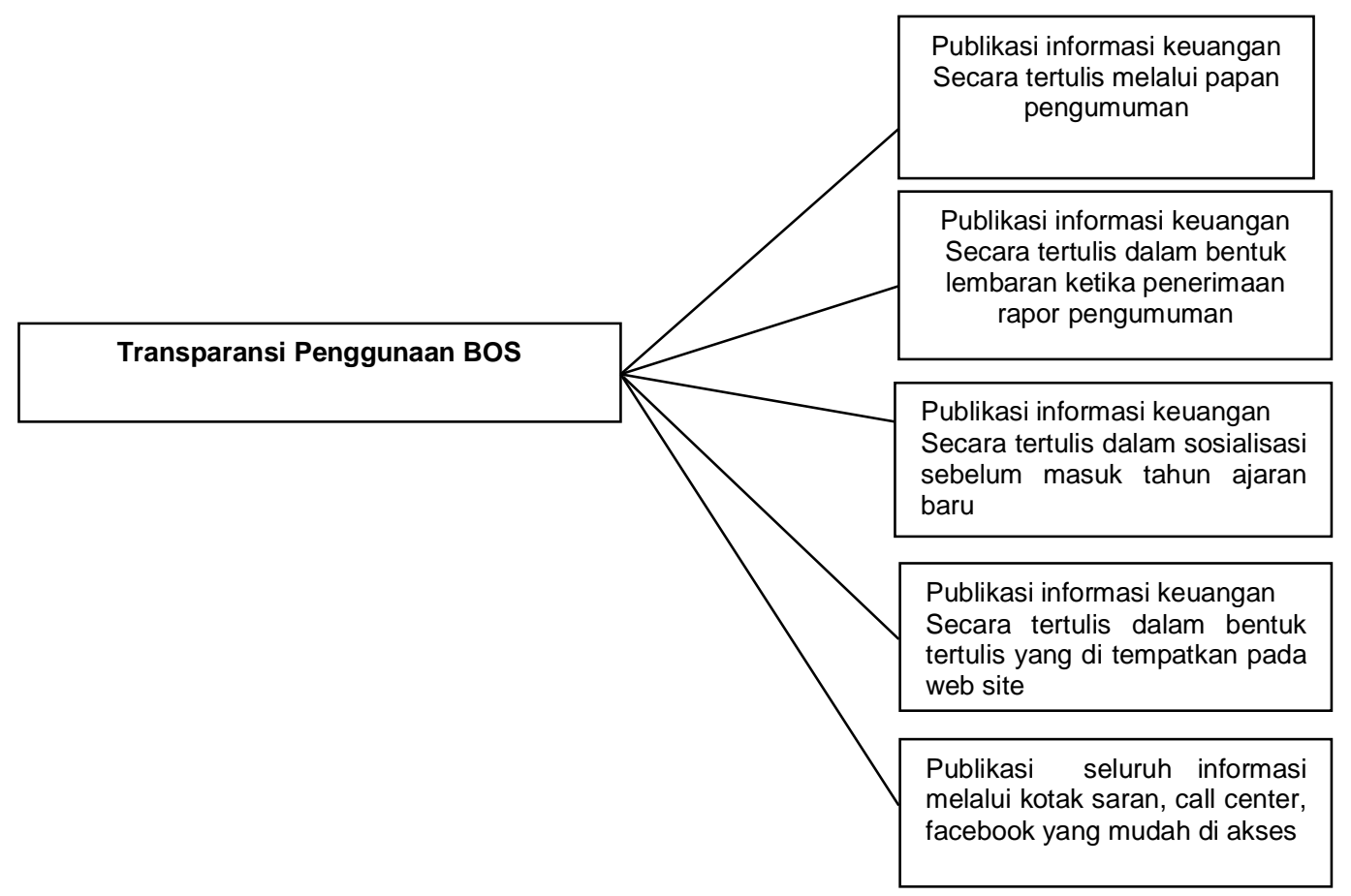

Gambar 2. Transparansi Penggunaan BOS 
madrasah dengan bendahara madrasah yang memiliki kebijakan yang berbeda dalampengukurannya dilakukan secara individu. Namun berbeda tingkat kepentingan ketikapengukuran dilakukan secara bersamaan antara kepala madrasah dan bendahara dalam situasi sosial yang bersamaan menghasilkantingkat kepentingan dalam satu kolaborasi kebijakan serta kepentingan yang sama.

Berdasarkan hasil analisis terlihat bahwa perbedaan antar indikator satu dengan yang lainnya tidak begitu jauh seperti pada hasil skalaprioritas daripengukuran sebelumyayang dilakukan secara individu. Pengukuran tingkat kepentingan informan secara bersaman, realitanya menghasilkan skala prioritas yang perbedaan indikator kepentingan tersebut tidak cukup begitu besar antara indikator satu dengan yang lainnya.

Nilai transparansi pada satuan pendidikan Perwanida muncul dari indikator skala prioritas tertinggiketika pertanggungjawaban tersebut di publikasikan pada saat sosialisasi sebelum tahun ajaran baru sebesar $23,2 \%$. Publikasi melalui kotak saran call center, facebook, twitter yang pada dasarnya untuk mempermudah akses informasi mempunyai skala prioritas $22,3 \%$. Indikator tersebut di atas menggambarkan bahwa nilai kepentingan transparansi dari skala prioritas tersebut di atas tidak begitu besar perbedaannya.

Publikasi informasi laporan keuangan pada walimurid secara tertulis dalam bentuk lembaran melalui penerimaan rapor mempunyai nilai kepentingan sebesar $20 \%$. Hal ini menunjukan bahwa antara tingkat kepentingan dari indikator satu dengan lainnya sedikit sekaliperbedaan skala prioritas daripengukuran kepentingan informan yang dilakukan secara bersamaan.
Untuk indikator publikasi informasi laporan keuangan pada walimurid yang ditempatkan pada web site sekolah menempati skala prioritas keempat dengan nilai kepentingan sebesar 19,3\%. Sedangkan indikator yang mempunyai skala prioritas terakhir adalah publikasi informasi laporan keuangan pada walimurid secaratertulismelaluipapan pengumuman sekolah yang mempunyai nilaikepentingan sebesar $15,2 \%$.

Dalam petunjuk teknik BOS terdapat indikator yang menunjukan adanya keterbukaan dalam pertanggungjawaban keuangan kepada publik adalah sebagai berikut: Pertama, mengumumkan besarnya dana yang diterima dan dikelola oleh sekolah dan rencana penggunaan dana BOS di papan pengumuman sekolah yang ditandatangani oleh Kepala sekolah, bendahara, dan ketua komite sekolah. Kedua, mengumumkan penggunaan dana BOS di papan pengumuman

Hasil temuan peneliti terhadap nilai transparansi berdasarkan tingkat kepentingan informan jika dibandingkan dengan nilai serta implementasi transparansi pada petunjuk teknik BOS menunjukan bahwa publikasi informasi laporan keuangan pada walimurid secara tertulis pada papan pengumuman sekolah mempunyai nilai kepentingan dan skala prioritas paling akhir di satuan pendidikan Perwanida. Jika ditinjau dari petunjuk teknik BOS keterbukaan dalam pertanggungjawaban keuangan publik salah satu indikatornya adalahmengumumkan besarnya dana yang diterima dan dikelola serta penggunaan dana BOS di papan pengumuman. Hal ini menunjukan bahwa realita implementasi di satuan pendidikan sangat berbeda dengan kebijakan pemerintah yang tertuang dalam sebuah petunjuk teknik dalam pengelolaan keuangan bantuan operasional sekolah. 


\section{Penutup}

Peneliti dapat mengambil beberapa simpulan tentang pengukuran skala prioritas terhadap tingkat kepentingan informan, bahwa pada prinsipnya kebijakan akuntabilitas yang sudah diimplementasikan di satuan pendidikan yang berkategori ruang lingkup satuan pendidikan besar mempunyai interpretasi berbeda antara pelaksana teknik dan pihak pegambil keputusan (bendahara dan kepala madrasah). Hal ini terlihat bahwa indikator dari beberapa kriteria yang digunakan sebagai standar pengukuran mempunyai skala prioritas yang berbeda. Skala prioritas akuntabilitas informan berdasarkan hasil pengukuran nilai kepentingan antara bendahara dan kepala madrasah mempunyai nilai yang berbeda sehingga menimbulkan konflik kepentingan antara pelaksana teknik dan pihak pengambil keputusan dalam hal pengelolaan dan kebijakan keuangan.

Konflik kepentingan antara pelaksana teknik dengan pihak pengambil kebijakan diukur dari tingkat kepentingan ketika dalam situasi sosial yang bersamaan menghasilkan nilai indikator tingkat kepentingan yang menghasilkan sebuah komitmen kebijakan dari sebuah proses akuntabiltas. Dalam hal ini, konfilk kepentingan antara pelaksana teknik dengan pihak pengambil keputusan bisa mengcover skala prioritas tingkat kepentingan mereka yang merupakan bagian dari sebuah komitmen kebijakan terhadap pengelolaan keuangan terhadap beberapa tingkat kepentingan informan tersebut. Komitmen kebijakan terhadap pengelolaan keuangan merupakan salah satu bagian dari sebuah proses nilai-nilai akuntabilitas yang dapat diimplementasikan di sebuah satuan pendidikan.

Di sisi lain, nilai-nilai transparansi dari sebuah pertanggungjawaban keuangan pihak pengelola anggaran muncul ketika se- buah proses penggunaan anggaran yang dipublikasikan kepada pihak stakeholder internal dan eksternal dari satuan pendidikan. Implementasi publikasi yang diasumsikan pihak pengelola anggaran telah mengalami beberapa pergeseran. Jika mengacu pada pelaksanaan petunjuk teknik kebijakan pemerintah menggunakan standar yang ada yaitu indikator keterbukaan dalam pertanggungjawaban dengan mengumumkan besarnya dana yang diterima dan dikelola oleh sekolah serta rencana penggunaan dana BOS di papan pengumuman sekolah.

Dalam implementasinya satuan pendidikan Perwanida yang merupakan kategori sekolahbesar munculindikator publikasiyang sifatnya modernisasi seperti publikasi via website, call center, facebook yang publikasi ini dirasa akan lebih efektif dan mempermudah akses informasi dibandingkan dengan standar pada petunjuk teknik. Dengan munculnya indikator keterbukaan seperti yang ada di satuan pendidikan yang berkategori besar, maka akan mempermudah publik seperti stakeholder internal dan eksternal dalam mengakses informasi tanpa harus terbatas dalam ruang dan waktu.

Regulasi pemerintah juga mendukung dalam menentukan pertanggungjawaban yang bersifat akuntabel dan transparan. Realitanya pemerintah belum mengatur standar pagu terhadap alokasi penggunaan dana bantuan operasional sekolah yang berkaitan langsung dengan kepentingan siswa dan sifatnya operasional yang dapat mendukung secara tidak langsung terhadap kepentingan siswa. Regulasi pemerintah seperti batasan pengalokasian dana akan dapat memberikan keseragaman kebiajakanterhadap alokasi penggunaan dana bantuan dalam implementasinya di setiap periode anggaran satuan pendidikan. 
Analisa Akuntabilitas dan Transparansi... (Nurul Hariswati)

\section{DAFTAR PUSTAKA}

Budiardjo, Miriam. 1998. Menggapai Kedaulatan Untuk Rakyat. Mizan. Bandung.

Boy, Denny dan Siringoringo, Hotniar. 2009. Analisis Pengaruh Akuntabilitas dan Transparansi Pengelolaan Anggaran Pendapatan dan Belanja Sekolah (APBS) terhadap Pertisipasi Orang Tua Murid. JurnalEkonomi Bisnis No. 12 Vol. 14, Agustus 2009.

Baxter, J. A. dan W. F. Chua 1998. Doing Field Research: Practice and MetaTheory in Counterpoints. Journal of Management Accounting Research 10.pp. 69-87

Creswell, J. W. dan D. L. Miller. 2000. Determining Validity in Qualitative Inquiry. Theory Into Practice, 39, 3, pp.124130

Creswell, J. W. 1998. Qualitative Inquiry and Research Design: Choosing Among Five Tradition. SAGE Publications. London.

Choiri, N. H. 2003. Akuntabilitas Kinerja Dinas Pendidikan Kabupaten Malang (Studi Kasus tentang Akuntabilitas AdministratifPelaksana Program Wajib Belajar Pendidikan Dasar Sembilan Tahun di Kecamatan Bululawang Kabupaten Malang. Jurnal Ilmiah Administrasi Publik, Vol. IV, No. 1, 2003

Desi, Diyah Parwita. 2008. Evaluasi Akuntabilitas dan Transparansi Pengelolaan Keuangan Sekolah Studi Kasus Pengelolaan Keuangan SMP Negeri di Kabupaten Banyumas, Tesis, Program Magister Akuntansi, ProgramPascasarjana Universitas Indonesia.
Emzir. 2012. Metodologi Penelitian Kualitatif: Analisa Data (Cetakan ke-3). PT. Raja Grafindo Persada. Jakarta.

Glaser, B. dan A. Strauss. 1967. The Discovery of Grounded Theory: Strategies for Qualitative Research. Aldine Press. Chicago.

Hess, David. 2005. Social Reporting and New Governance Regulation: The Prospects of Achieving Corporate Accountability through Transparency, Ross School of Business University of Michigan. Business Ethics Quarterly, Vol.17, pp. 453-476

Jawa Pos. 2012. Banyak Dana BOS yang Salah Sasaran. Jawa Pos, 14 April 2012.

Kemendiknas dan Kemenag. 2011. Panduan Bantuan Operasional Sekolah, Peningkatan Manajemen Melalui Penguatan Tata Kelola dan Akuntabilitas di Sekolah/Madarsah. Jakarta.

Kusrini. 2007. Konsep dan Aplikasi Sistem Pendukung Keptusan (Cetakan pertama). Penerbit Andi. Yogyakarta.

Krina P, Lolina Lalolo. 2003. Indikator dan Alat Ukur Prinsip Akunbilitas, Transparansi dan Partisipasi. Sekretariat Good Public Governance. Badan Perencanaan Pembangunan Nasional. Jakarta.

KNKG (Komite Nasional Kebijakan Governance). 2010 Pedoman Umum Good Public Governance Indonesia. http://www.google.co.id. Diakses 15 Maret 2012.

Kompas. 2008. Bappenas akui Alokasi Anggaran Pendidikan di Depag dan 
Ekonomika-Bisnis Vol. 6 No.1 Bulan Januari Tahun 2015. Hal 75-88

Diknas belum Final. Kompas, Senin

1 September 2008. Http:// www.google.co.id. Diakses 15 Maret 2012

Lazuardi Birru. 2012. Berita Pendidikan: Alokasi Anggaran Sekolah Negeri dan Swasta belum adil, http:// www.google.co.id. Diakses 24 Agustus 2012.

Lincoln, Y. S. dan E. G. Guba. 1986. Naturalistic Inquiry. Sage. California.

Moleong, Lexy J. 2010. Metode Penelitian Kualitatif. Edisi Revisi (Cetakan ke10). PT. Remaja Rosdakarya. Bandung.

Miles, M.B dan Huberman, A.M. 1992. Analisa Data Kualitatif. UI Press. Jakarta.

Mahsun, Moh. 2011. Pengukuran Kinerja Sektor Publik. Konsep dan Praktik Pengukuran Kinerja di Lingkungan Organisasi sektor Publik,

http://www.mohmahsun.blogspot.com/2011/ 04/akuntabilitas-kinerja.html. Diakses 25 Pebruari 2012.

Mardiasmo. 2002. Akuntansi Sektor Publik. Penerbit Andi. Yogyakarta.

2006. Pewujudan Transparansi danAkuntabilitas Publik MelaluiAkuntansiSektor Publik: Suatu Sarana Good Governance. Jurnal Akuntansi Pemerintahan, Vol. 2, No. 1, Mei 2006.

Mudib, Ansori 2011. Akuntabilitas Pelaksanaan Bantuan Operasional Sekolah (BOS) di Kabupaten Gresik (Studi Tentang Akuntabilitas Administrasi dan Akuntabilitas Profesional dalam Program
Bantuan Operasional Sekolah (BOS) di Dinas Pendidikan Kabupaten Gresik). Minor Tesis, Program Akuntansi, Universitas Brawijaya.

Rustandi, Agus Sekjen GGW (Garut Government Watch). Dana BOS Triwulan 12012 sudah Bocor 10 persen, http:/ /www.antikorupsi.org/new. Diakses tanggal 20 April 2012.

Ryan, James E. 2002. Flexisibility and Accountability in Public Education, Public Law and Legal Theory Research Paper Series.University Of VirginiaSchool of Law, Social Science Research Network Electronic Paper Collection. No. 02-20

Republik Indonesia. Undang-Undang Nomor 20 Tahun 2003 tentang Sistem Pendidikan Nasional.

Undang-Undang nomor 17 tahun 2003 tentang Keuangan Negara . Undang-Undang Nomor 15 Tahun 2004 tentang Pemeriksaan Pengelolaan dan Tanggung Jawab Keuangan Negara

.Undang-Undang Nomor 1 Tahun 2004 Perbendaharaan Negara

Peraturan Pemerintah Nomor 48 tahun 2008 tentang Pendanaan Pendidikan

. Peraturan Pemerintah Nomor 24 tahun 2005 tentang Kerangka Konseptual Akuntansi Pemerintah.

Permendiknas Nomor 24 Tahun 2007 tentang standar Sarana dan Prasarana sekolah dasar/ madrasah ibtidaiyah. 
Analisa Akuntabilitas dan Transparansi... (Nurul Hariswati)

Peraturan Pemerintah

Nomor 19 Tahun 2005 tentang Standar Nasional Pendidikan pasal 86 mengenai akreditasi satuan pendidikan

Sadjiarto, Arja. 2000. Akuntabilitas Dan Pengukuran Kinerja Pemerintahan. Jurnal akuntansi dan Keuangan. Vol.2 No:2 138-150

Suharto, Edi. 2005. Membangun Masyarakat Memberdayakan Rakyat, Kajian Strategis Pembangunan Kesejahteraan Sosial dan Pekerjaan Sosial. Refika Aditama. Bandung.

Santoso, Puji B. 2005. Akuntabilitas dan Transparansi Pengelolaan Keuangan, Partisipasi Pembiayaan dan efisiensi Penyelenggaraan Pendidikan SMP Negeri Kabupaten Banyumas. Tesis, Program Magister Akuntansi, ProgramPascasarjana Universitas Gajah Mada.

Susilo, L.J dan Simamarta, K. 2007. Good Coporate Governance pada Bank: Tanggung Jawab Direksi dan Komisaris dalam Melaksanakannya. PT Hikayat Dunia. Bandung.

Sutedjo. 2009. Persepsi Stakeholders terhadap Transparansi dan Akuntabilitas Pengelolaan Keuangan Sekolah (Studi Kasus SMP Standar Nasional Kabupaten Kendal), Tesis, Program Magister Akuntansi, ProgramPascasarjana Universitas Diponegoro.

Sugiyono. 2010. Metode Penelitian Bisnis. Cetakan ke-15. Bandung: AlfaBeta.
Topik Petang. 2012. Mengupas Penyelewengan Pengelolaan BOS. ANTV. 10 Maret 2012.

Wijaya, David. 2009. Implikasi Manajemen Keuangan Sekolah Terhadap Kualitas Pendidikan. Jurnal Pendidikan Penabur vol. 8, no.13, $80-96 . \quad h \underline{\text { ttp:// }}$ www.google.co.id. Diakses 15 Maret 2012

Yin, R.K.. 2012. Aplilcation of Case Study Research Design and Methods, Second Edition. M.Djauzi Mudzakir. Studi Kasus Desain dan Metode. PT RajaGrafindo Persada. Jakarta. 
